\title{
Effects of Interactions among Gene Polymorphisms of the Renin-Angiotensin-Aldosterone System on Hypertension in Turkish People from Southeast Anatolia
}

\begin{abstract}
Abdullah Arpac1 ${ }^{*}$, Meral Urhan-Kucuk ${ }^{2}$, Aysegul Bayramoglu ${ }^{3}$, Halil İbrahim Guler ${ }^{4}$, Hasret Ecevit ${ }^{2}$, Arif Suner ${ }^{5}$, Sevim Karakaş-Celik ${ }^{6}$

1. Hatay Mustafa Kemal University, Faculty of Medicine, Department of Biochemistry, Hatay, Turkey 2. Hatay Mustafa Kemal University, Faculty of Medicine, Department of Medical Biology, Hatay, Turkey 3. Artvin Çoruh University, School of Health Sciences, Department of Nutrition and Dietetics, Artvin, Turkey

4. Karadeniz Technical University, Faculty of Science, Department of Biology, Trabzon, Turkey 5. Adiyaman University, Faculty of Medicine, Department of Cardiology, Adiyaman, Turkey 6. Bülent Ecevit University, Science and Art Faculty, Department of Molecular Biology and Genetics, Zonguldak, Turkey

Abstract

Introduction: Hypertension (HT) is characterized by high blood pressure. The reninangiotensin-aldosterone system (RAAS) plays a crucial role in blood pressure (BP) regulation by maintaining vascular tone and the water-sodium balance. We aimed to investigate whether there is any relation between AGT (M235T), ACE (I/D), and AGTR1 (A1166C) genetic polymorphisms and hypertension among Turkish people from Southeast Anatolia.

Method and Results: A total of 210 individuals, consisting of 102 healthy controls and 108 patients with essential hypertension admitted to the Cardiology Department of the Adlyaman University Research and Application Hospital were included the study. DNA isolation was performed from the blood samples via commercial kit. Genotype determination was determined using the polymerase chain reaction-restriction fragment length polymorphism (PCR$R F L P)$ technique. Statistically significant differences were found between the control and patient groups in terms of genotype distribution and allelic frequencies of ACE I/D polymorphisms. Significant differences were found in the frequencies of ICM, DCM, DCT, DAT between the patient and control groups.

Conclusions: In this study, we found a significant association of ACE I/D polymorphism with HT, and we showed that the I allele can increase the risk of HT in Turkish people from Southeast Anatolia. Although we did not find any association between independent AGT M235T and AGT1R A1166C polymorphisms and HT, we observed that the $D C M, D C T$, and DAT haplotypes of ACE/AGTIR/AGT polymorphisms reduced the risk of hypertension, while the ICM haplotype increased it.
\end{abstract}

Keywords: hypertension, renin-angiotensin-aldosterone system (RAAS), genetic variations, ACE I/D, haplotype

Received: $20^{\text {th }}$ September 2018; Accepted: $7^{\text {th }}$ January 2019; Published: $11^{\text {th }}$ February 2019

*Corresponding author: Abdullah Arpac1, Hatay Mustafa Kemal University, Faculty of Medicine, Department of Biochemistry, Hatay, Turkey. E-mail: arpaci57@gmail.com 


\section{Introduction}

Hypertension (HT) is characterized by high blood pressure known to be a crucial risk factor for various disorders such as cardiovascular, neurological, and renal diseases. HT is the most frequent cause of death worldwide as well as in Turkey. It is a major threat to public health (1$5)$. There is strong evidence that interactions of environmental and genetic factors contribute to the development of HT (6-9). The renin-angiotensin-aldosterone system (RAAS) is known to have an important role in blood pressure (BP) regulation by maintaining vascular tone and the water-sodium equilibrium. Angiotensinogen is hydrolyzed by renin to form the angiotensin-I that is then converted by angiotensin-converting enzyme (ACE) into the angiotensin-II (Ang-II) in RAAS pathways. The primary receptor of Ang-II is the Ang-II receptor type 1 (AGT1R). The expression pattern at both gene and protein levels of the molecular players mentioned above plays a crucial role in HT (10-12). Various HT candidate genes that are related to renin angiotensin system (RAS) have been shown to contribute to BP regulation by different molecular mechanisms in the development of HT (10). RAAS genes including ACE, AGT, and AGT1R are polymorphic genes. There are many studies investigating the relation between RAAS gene polymorphisms and the development and incidence of HT; however, conflicting results were also reported $(3,10,12-15)$. It is possible that selection criteria of patients, environmental factors (e.g. geographic region), and ethnicity may contribute to the contradictory data from several studies about gene polymorphisms regarding HT $(10,12,16)$.

In this study, we aimed to investigate if there is any relation between $A G T$ (M235T), $A C E$ (I/D), and AGT1R (A1166C) gene polymorphisms and HT among Turkish people in the region of Southeast Anatolia.

\section{Materials and Methods}

\section{Selected Population}

This study included 210 individuals consisting of 102 healthy controls who and whose relatives possess no cardiovascular diseases, and 108 patients with persistent and pathological high blood pressure who were admitted to the Cardiology Department of Adiyaman University Research and Application Hospital. In the present study, the confirmation by Adiyaman University Ethic Committee (date: 02.10.2013; number: 2013/101.1) and a written consent from each subject were provided after participants had been properly informed. All experiments were performed abided by the Declaration of Helsinki. Individuals who had aortic coarctation, previous cardiac surgery, valve stenosis greater than mild degree or regurgitation, complex congenital heart disease, chronic kidney disease, respiratory illness, acute infection, hepatic dysfunction or chronic inflammatory diseases were not included in the current study. The hypertensive patients who were receiving anti-hypertensive medication and the patients with essential hypertension were included in the study. There was no blood relation between the individuals included in the study. After a 5-minute rest in the sitting position for all individuals, blood pressure was measured three times on both upper limbs by using an automatic manometer (Omron M4 Plus, Omron Healthcare Europe, Hoofddorp, and Holland). The average value of the second and the third measurements were taken into account. The values exceeding $140 \mathrm{mmHg}$ for systolic blood pressure (SBP) and $90 \mathrm{mmHg}$ for diastolic blood pressure (DBP) were diagnosed as HT (17).

\section{Genotype determination}

Genomic DNA was isolated from whole blood samples, which were collected in tubes containing EDTA, with a DNA isolation kit (Thermo Scientific, Lithuanian). Genotype determination 
was carried out by using the polymerase chain reaction-restriction fragment length polymorphism (PCR-RFLP) technique. Determination of polymorphisms in the ACE I/D (18), AGT1R A1166C (19) and AGT M235T (20) was performed in accordance with the previously described method, with minor modifications, as explained below.

A 287-bp insertion or deletion in intron 16 of the ACE gene, which is called ACE I/D polymorphism, was determined with PCR in which forward primer 5- CTGCAGACCACTCCCATCCTTTCT-3 and the reverse primer 5- GATGTGGCCATCACATTCGTCAGAT-3 were used. In a total volume of $50 \mu \mathrm{L}$, PCR was carried out, consisting of 10 pmol of each primer, $0.5 \mathrm{mM}$ of each dNTP, $2 \mathrm{U}$ Taq DNA polymerase, $1.5 \mathrm{mM} \mathrm{MgCl} 2 \mathrm{~s}$, and $1 \mu \mathrm{L}$ genomic DNA. PCR was carried out in a thermal cycler (Applied Bio systems Veriti); following an initial denaturation at $94{ }^{\circ} \mathrm{C}$ for $5 \mathrm{~min}, 35$ rounds of thermo cycling consisting of denaturation at $94{ }^{\circ} \mathrm{C}$ for $1 \mathrm{~min}$, annealing at $58{ }^{\circ} \mathrm{C}$ for $40 \mathrm{~s}$, and extension at $72{ }^{\circ} \mathrm{C}$ for $1 \mathrm{~min}$, then a final extension at $72{ }^{\circ} \mathrm{C}$ for $5 \mathrm{~min}$. The amplification samples were run on an agarose gel $(2 \%)$ and visualized by ultraviolet following ethidium bromide staining. The genotypes were determined to be homozygous deletion (DD) (190-bp), homozygous insertion (II) (490 bp), and the heterozygous (ID) insertion and deletion (490 bp/190 bp) $(18,21,22)$.

For AGT M235T polymorphism, the $303 \mathrm{bp}$ region of the angiotensinogen gene was amplified with PCR by using forward primer 5' GATGCGCACAAGGTC CTGTC3' and reverse primer 5'CAG GGT GCT GTC CAC ACT GGA CCC C 3'. PCR was carried out in a total volume of $50 \mu \mathrm{L}$, consisting of $10 \mathrm{pmol}$ of each primer, 0.5 $\mathrm{mM}$ of each dNTP, $2 \mathrm{U}$ Taq DNA polymerase, $1.5 \mathrm{mM} \mathrm{MgCl} 2$, and $1 \mu \mathrm{L}$ genomic DNA. Amplification was performed in a thermal cycler (Applied Biosystems Veriti); after an initial denaturation at $94{ }^{\circ} \mathrm{C}$ for $5 \mathrm{~min}, 35$ rounds of ther- mocycling consisting of denaturation at $94{ }^{\circ} \mathrm{C}$ for $1 \mathrm{~min}$, annealing at $57^{\circ} \mathrm{C}$ for $40 \mathrm{~s}$, and extension at $72{ }^{\circ} \mathrm{C}$ for $1 \mathrm{~min}$, ending with a last extension at $72{ }^{\circ} \mathrm{C}$ for $5 \mathrm{~min}$. Then the PCR products were digested using the PsyI, run on a $2 \%$ agarose gel, and visualized by ultraviolet transillumination following staining with ethidium bromide. Two fragments, the longer one consists of 279 bp and the shorter one contains $24 \mathrm{bp}$, appeared on the agarose gel after restriction digestion. The genotypes were determined to be homozygous MM (303-bp), homozygous TT (only a single 247-bp), and heterozygous MT (303-bp/247-bp) (20). For AT1 A1166C polymorphism, the 410 bp region of the angiotensin II type 1 receptor (AT1R) gene was amplified with PCR by using forward-primer 5'- AGAAGCCTGCACCATGTTTTGAG -3' and reverse-primer-5'- CCTGTTGCTCCTCTAACGATTTA -3'. PCR was carried out in a total volume of $50 \mu \mathrm{L}$, consisting of 10 pmol of each primer, $0.5 \mathrm{mM}$ of each dNTP, 2 U Taq DNA polymerase, $1.5 \mathrm{mM}$ $\mathrm{MgCl} 2$ and $1 \mu \mathrm{L}$ genomic DNA. PCR was carried out in a thermal cycler (Applied Bio systems Veriti); after an initial denaturation at $94{ }^{\circ} \mathrm{C}$ for $5 \mathrm{~min}, 35$ rounds of thermocycling consisting of denaturation at $94{ }^{\circ} \mathrm{C}$ for $1 \mathrm{~min}$, annealing at $62^{\circ} \mathrm{C}$ for $40 \mathrm{~s}$ and extension at $72{ }^{\circ} \mathrm{C}$ for $1 \mathrm{~min}$, ending with a final extension at $72{ }^{\circ} \mathrm{C}$ for $5 \mathrm{~min}$. Then the PCR products were digested using the Hind III, run on a $2 \%$ agarose gel, and visualized by ultraviolet transillumination after ethidium bromide staining. RFLP was ended up with the generation of $219 \mathrm{bp}$ and $191 \mathrm{bp}$ fragments. The genotypes were determined to be homozygous AA (410 bp), homozygous CC (219 bp and 191 bp) and heterozygous AC (410 bp, 219 bp, and 191 bp (19).

\section{Statistical analysis}

In this study, the whole data was statistically analyzed using the packaged program IBM SPSS Statistics 2.0 software. The $\chi 2$ test was used to compare gender and genotype and al- 
lele frequencies of the ACE, AGT and AGT1R polymorphisms between HT patients and controls. The association between ACE, AGT, and AGT1R polymorphisms and HT was modeled through binary logistic regression analysis and odds ratio (OR) and 95\% confidence interval $(95 \% \mathrm{CI})$ were calculated to compare HT risk among genotypes. Such variables as age, height, weight, etc. were compared between groups with Mann-Whitney U Test for the non-normal variables and Student's t-Test for the normally distributed variables. Parameter values were compared between two groups with two independent sample t- and Mann Whitney-U tests. Additionally, to determine the normality, Shapiro-Wilk Test was used. $\mathrm{p}<0.05$ was accepted as statistically significant.

\section{Results}

The demographic and biochemical characteristics of the hypertensive patients and normotensive control groups are displayed in Table 1. There were statistically significant differences between the control and patient groups with respect to systolic blood pressure (SBP) $(\mathrm{p}<0.001)$ and diastolic blood pressure (DBP) $(\mathrm{p}=0.05)$. However, there was no significant difference regarding other baseline characteristics (age, gender distribution, body mass index (BMI), high density lipoproteins (HDL), low density lipoproteins (LDL), triglycerides (TG), or diabetes mellitus $(\mathrm{DM})(\mathrm{p}>0.05)$. Demographic and biochemical characteristics of study groups are shown in Table 1.

Table 1. Demographic and biochemical characteristics of study groups.

\begin{tabular}{lccc}
\hline Variables & $\begin{array}{c}\text { Control (102) } \\
\mathbf{n}(\mathbf{\%}) \\
\text { mean } \pm \text { SD } \\
\text { median (min-max) }\end{array}$ & $\begin{array}{c}\text { HT 108 } \\
\mathbf{n}(\mathbf{\%}) \\
\text { mean } \pm \text { SD } \\
\text { median (min-max) }\end{array}$ & p Value \\
\hline Gender (M/F) & $45 / 57(44.1 / 55.9)$ & $36 / 72(33.3 / 66.7)$ & $0.120^{*}$ \\
\hline Age & $55(36-92)$ & $56(31-86)$ & $0.971^{* *}$ \\
\hline Weight & $75.77 \pm 11.63$ & $80.72 \pm 10.92$ & $0.002^{* * *}$ \\
\hline BMI & $28.04(19.38-342.00)$ & $32.59(22.31-313)$ & $0.071^{* *}$ \\
\hline Systolic BP, mmHg & $120(100-180)$ & $140(110-180)$ & $<0.001^{* *}$ \\
\hline Diastolic BP, mmHg & $80(60-100)$ & $90(70-110)$ & $<0.001^{* *}$ \\
\hline TC & $190(112-281)$ & $194(119-404)$ & $<0.001^{* *}$ \\
\hline HDL & $42(20-78)$ & $40(24-73)$ & $0.341^{* *}$ \\
\hline LDL & $108(34-275)$ & $118(22-275)$ & $0.151^{* *}$ \\
\hline TG & $163(53-755)$ & $170(52-1131)$ & $0.311^{* *}$ \\
\hline DM (+/-) & $24 / 78(23.53 / 76.47)$ & $25 / 83(23.1 / 76.9)$ & $1.000^{*}$ \\
\hline
\end{tabular}

HT, Hypertensive; BMI, Body mass index; BP, Blood pressure; TC, Total cholesterol; HDL, High-density lipoprotein; LDL, Low-density lipoprotein; TG, Triglycerides; DM, Diabetes mellitus; SD, Standard deviation.

* $\chi 2$ test; ** Mann-Whitney U test, ${ }^{* * *}$ Student's $t$ test. 


\section{ACE I/D:}

Statistically significant differences were determined when control and patient groups were compared with respect to genotype distribution and allelic frequencies of ACE I/D polymorphisms $(p<0.001)$. The genotype distributions and allele frequencies of the polymorphisms between hypertensive patients and normotensive controls are shown in Table 2.

\section{AGT M235T:}

When patient and control groups were compared with respect to genotype distribution and allelic frequencies of AGT M235T polymorphisms, no significant difference was determined $(p>0.05)$. The genotype distributions and allele frequencies of the polymorphisms between hypertensive patients and normotensive controls are shown in Table 2.

\section{AGT1R A1166C:}

When control and patient groups were compared in terms of genotype distribution and allelic fre- quencies of AGT1R A1166C polymorphisms, no significant difference was determined $(p>0.05)$. The genotype distributions and allele frequencies of the polymorphisms between hypertensive patients and normotensive controls are shown in Table 2.

\section{Haplotypes:}

Haplotype distributions of ACE/AGT1R/AGT polymorphisms were compared between control and patient groups $(\mathrm{p}<0.001$; Table 3$)$. The haplotypes of the polymorphisms of hypertensive patients and normotensive controls were shown in Table 3.

\section{Discussion}

The renin angiotensin system (RAS) takes an important part in the regulation of water-salt balance in the human body which is associated with HT. Many studies reported that there is a relationship between RAS gene polymorphisms, such as angiotensin converting enzyme (ACE $\mathrm{I} / \mathrm{D}$ ), angiotensinogen (AGT M235T), and the

Table2. The genotype distributions and allele frequencies of the polymorphisms between hypertensive patients and normotensive controls.

\begin{tabular}{|c|c|c|c|c|c|c|c|}
\hline SNP & & $\begin{array}{c}\text { Geno- } \\
\text { type }\end{array}$ & $\begin{array}{c}\text { Control n (\%) } \\
102(100) \\
\end{array}$ & $\begin{array}{l}\text { HT n (\%) } \\
108(100)\end{array}$ & $p$ value ${ }^{a}$ & OR (95\% CI) & $p$ value ${ }^{*}$ \\
\hline \multirow{5}{*}{$A C E I / D$} & \multirow{3}{*}{ Genotype } & II & $21(20.6)$ & $66(61.1)$ & \multirow{3}{*}{$<0.001$} & Reference & $<0.001$ \\
\hline & & ID & $46(45.1)$ & $36(33.3)$ & & $0.249(0.129-0.480)$ & $<0.001$ \\
\hline & & DD & $35(34.3)$ & $6(5.6)$ & & $0.055(0.020-0.148)$ & $<0.001$ \\
\hline & \multirow{2}{*}{ Allele } & $\mathbf{I}$ & $88(43.1)$ & $168(77.8)$ & \multirow{2}{*}{$<0.001$} & Reference & \\
\hline & & D & $116(56.9)$ & $48(22.2)$ & & $0.217(0.147-0.331)$ & \\
\hline \multirow{5}{*}{$\begin{array}{l}A G T 1 R \\
A 1166 C\end{array}$} & \multirow{3}{*}{ Genotype } & $\mathbf{C C}$ & $2(2.04)$ & $1(0.9)$ & \multirow{3}{*}{0.670} & Reference & 0.677 \\
\hline & & $\mathbf{A C}$ & $83(81.32)$ & $92(85.2)$ & & $2.244(0.200-25.205)$ & 0.513 \\
\hline & & $\mathbf{A A}$ & $17(16.64)$ & $15(13.9)$ & & $1.765(0.145-21.474)$ & 0.656 \\
\hline & \multirow{2}{*}{ Allele } & $\mathbf{C}$ & $87(42.6)$ & $94(43.5)$ & \multirow{2}{*}{0.921} & Reference & \\
\hline & & $\mathbf{A}$ & $117(57.4)$ & $122(56.5)$ & & $0.962(0.653-1.418)$ & \\
\hline \multirow{5}{*}{$\begin{array}{l}A G T \\
M 235 T\end{array}$} & \multirow{3}{*}{ Genotype } & MM & $10(9.8)$ & $16(14.8)$ & \multirow{3}{*}{0.522} & Reference & 0.526 \\
\hline & & MT & $48(47.1)$ & $50(46.3)$ & & $0.651(0.269-1.576)$ & 0.341 \\
\hline & & TT & $44(43.1)$ & $42(38.9)$ & & $0.597(0.244-1.462)$ & 0.259 \\
\hline & \multirow{2}{*}{ Allele } & $\mathbf{M}$ & $68(33.3)$ & $82(38.0)$ & \multirow{2}{*}{0.359} & Reference & \\
\hline & & $\mathbf{T}$ & $136(66.7)$ & $134(62.0)$ & & $0.817(0.548-1.219)$ & \\
\hline
\end{tabular}

aX2 analysis p-value; ${ }^{*}$ Logistic regression analysis $\mathrm{p}$-value 
Table 3. The haplotypes of the polymorphisms hypertensive patients and normotensive controls.

\begin{tabular}{lcccc}
\hline $\begin{array}{l}\text { Haplotypes } \\
\text { ACE-AGTIR-AGT }\end{array}$ & $\begin{array}{c}\text { Control } \\
\mathbf{1 0 2} \mathbf{~} \mathbf{( \% )}\end{array}$ & $\begin{array}{c}\text { HT } \\
\mathbf{1 0 8} \mathbf{~ n} \mathbf{( \% )}\end{array}$ & $\boldsymbol{p}$ value $^{*}$ & OR (95 \% CI) \\
\hline ICD-A1166C-M235T & $29(14.4 \%)$ & $52(24.1 \%)$ & $<0.001$ & Reference \\
\hline ICT & $26(12.9 \%)$ & $37(17.1 \%)$ & 0.503 & $0.794(0.403-1.561)$ \\
\hline IAM & $7(3.5 \%)$ & $20(9.3 \%)$ & 0.348 & $1.593(0.602-4.217)$ \\
\hline DCM & $19(9.4 \%)$ & $1(0.5 \%)$ & 0.001 & $0.029(0.004-0.231)$ \\
\hline DCT & $12(5.9 \%)$ & $4(1.9 \%)$ & 0.007 & $0.186(0.055-0.629)$ \\
\hline DAM & $13(6.4 \%)$ & $9(4.2 \%)$ & 0.053 & $0.386(0.147-1.012)$ \\
\hline IAT & $25(12.4 \%)$ & $59(27.3 \%)$ & 0.409 & $1.316(0.686-2.526)$ \\
\hline DAT & $71(35.1 \%)$ & $34(15.7 \%)$ & $<0.001$ & $0.267(0.145-0.492)$ \\
\hline $\boldsymbol{p}$ value $^{\mathrm{a}}$ & \multicolumn{3}{c}{$<0.001$} & \\
\hline
\end{tabular}

aX2 analysis p-value; ${ }^{*}$ Logistic regression analysis p-value.

angiotensin gene II type 1 receptor $(A G T 1 R$ $A 1166 C)$ and HT in various populations $(3,16$, 20, 23). However, there are also other studies which reflected contradictory results in this context. In the present study, we analyzed whether there is a correlation between polymorphisms of three RAAS genes and HT among affected Turkish people in the region of Southeast Anatolia. In our study, we found important differences between the normotensive control and hypertensive patient groups with respect to genotype distributions and allele frequencies of ACE I/D polymorphism $(\mathrm{p}<0.05)$. ACE I/D polymorphism was first identified by Rigat et al. in 1990 (24). Presence or absence of $287 \mathrm{bp}$ fragment in the 16th intron of the ACE gene gives rise to the polymorphism. Since it was identified, many studies have reported a correlation between the polymorphism and cardiovascular diseases, including HT and impaired serum ACE levels (2527) Ramu et al. reported a correlation between ACE I/D polymorphism and increasing risk of essential hypertension (EH). Furthermore, they argued that interaction between polymorphisms in $\mathrm{ACE}$ and angiotensinogen genes contributes to development of EH (23). In a study conducted by Cosenso Martin et al., the D allele (ID and DD genotypes) carriers had higher systolic blood pressure and 24-hour blood pressure compared to II genotype carriers, $(p=0.036$ and $p=0.042$, respectively). On the other hand, no difference was observed between the control and patient groups in terms of three genotypes (DD, ID, II) ( $p>0.05$ ) (28). Jiang et al. assessed that D allele frequencies were higher in the HT group than in the control group $(p<0.05)(10)$.

Contrary to our results, Gunes et al. did not find significant differences between ACE I/D genotype/allele frequencies and HT. In addition, they determined that the frequency of the $\mathrm{D}$ allele is higher than the I allele in Turkish patients with HT in the region of Central Anatolia (25). These discrepancies in ACE I/D genotype distributions and allele frequencies may be due to regional differences in Turkey. Jiang et al. showed a significant difference in the distribution of ACE I/D between HT and control groups. They observed that DD genotype frequency was higher in HT patients than controls, and II genotypes were similar in both groups (10). Consistent with our results, S. Abbas et al. showed in a North Indian population that, while DD genotype frequencies were lower in HT patients, II genotype frequencies were higher compared to controls $(\mathrm{p}<0.05)$ (DD/ID/II; 29.31/60.34/10.34\% in controls and $13.04 / 60.14 / 26.82 \%$ in the HT group) (29). Previous studies demonstrated that there were 
differences in genotype distributions and allele frequencies of ACE I/D polymorphism among different ethnicities (30-32). Yi et al. (2006) demonstrated significant differences in genotype distribution and allele frequencies of ACE I/D polymorphism between different ethnicities and genders as well as in systolic and diastolic blood pressures in hypertensive patients with different genotypes (33). These results indicate that ethnic variations should also be considered in studies related to ACE I / D polymorphism. When we evaluated the previous studies in terms of the effect of ACE I / D polymorphism on HT, there were different results regarding genotype distribution and allele frequency in different ethnic populations. Previous studies demonstrated that $\mathrm{D}$ allele frequency was lower in hypertensive patients compared to controls in South Asian populations in accordance with our work (34-38).

In the present study, we did not observe any association between genotype distributions and allele frequencies of AGT M235T and AGT1R A1166C polymorphisms in the HT group compared to the control group. In line with our results, Yang et al. claimed that there is no correlation between genotype distributions and allele frequencies of AGT M235T and AGT1R A1166C polymorphisms in HT group when compared to control group ( $\mathrm{p}=0.275$ and $\mathrm{p}=0.184$ respectively) (39). In contrast, Niu S et al. found higher MM genotype frequencies of AGT M235T polymorphism in the HT patient group compared with the control group (13).

There are other studies which could not find a relationship between HT and AGT M235T or AGT1R A1166C polymorphisms (10, 40, 41). In contrast, Niu W et al. found higher MM genotype frequencies of AGT M235T polymorphism in the patient group when compared with the control group (12). In addition, Niu S et al. argued that there is an important relation between AGT M235T and AGT1R A1166C polymorphisms and EH (13). In Turkish population, contrary to our results, Gunes et al. found significant difference between AGT1R A1166C polymorphism allele frequencies and HT. They determined that $\mathrm{C}$ allele frequency is higher in the HT group than in the control group (25).

In summary, the results of many similar studies performed with different populations are not in consistence with each other, likely due to strong ethnic and regional variations. Genetic variations in RAAS genes play an important role in the molecular etiology of EH. Therefore, alongside SNP studies, haplotype studies are also important in the identification of the association between RAAS genes and hypertension. In the haplotype analysis part of our study, the ratio of total haplotypes containing D allele were significantly lower in HT group. In line with that, this result is consistent with the significantly lower $\mathrm{D}$ allele frequency in the aforementioned hypertensive group.

\section{Conclusion}

In conclusion, we observed a significant association of ACE I/D polymorphism with HT in our study, and we showed that I allele can increase the risk of HT in the Turkish population of Southeast Anatolia. Although no correlation was found between independent AGT M235T and AGT1R A1166C polymorphisms and HT, we observed that DCM, DCT, and DAT haplotypes of ACE/AGT1R/AGT polymorphisms reduced the risk of HT while ICM haplotype increased it.

\section{Abbreviations}

Ang II: Angiotensin II; AGT: Angiotensinogen; ACE: Angiotensin converting enzyme; AGT1R: Angiotensin II receptor type 1; BMI: Body mass index; BP: Blood pressure; DBP: Diastolic blood pressure; DM: Diabetes mellitus; EH: Essential hypertension; HDL: High density lipoproteins; HT: Hypertension; LDL: Low density lipoproteins; PCR-RFLP: Polymerase chain reac- 
tion-Restriction fragment length polymorphism; RAS: Renin angiotensin system; RAAS: Renin angiotensin aldosterone system; SBP: Systolic blood pressure; TG: Triglycerides.

\section{Authors' Contribution}

AA and MUK designed and coordinated the study, participated in most of the analysis, examination of subjects, last revisions, and submitting the manuscript; $\mathrm{AB}$ and $\mathrm{HIB}$ coordinated the study, laboratory works, AS performed HT examination of subjects and blood sample collection, HE and SKC did statistical analysis and literature search.

\section{Acknowledgement}

This study was supported by a grant from the Research Foundation of Adiyaman University (TIPFBAP/2013-0004), Turkey.

\section{Conflict of interest}

The authors declare no conflict of interest.

\section{References}

1. Yamada Y, Matsuo H, Segawa T, Watanabe S, Kato K, Hibino T, et al. Assessment of the genetic component of hypertension. Am J Hypertens. 2006; 19(11):1158-65. DOI: 10.1016/j.amjhyper.2006.04.010

2. Tabassum N, Ahmad F. Role of natural herbs in the treatment of hypertension. Pharmacogn Rev. 2011; 5(9):30-40. DOI: 10.4103/0973-7847.79097

3. Bonfim-Silva R, GuimarAes LO, Souza Santos J, Pereira JF, Leal Barbosa AA, Souza Rios DL. Case-control association study of polymorphisms in the angiotensinogen and angiotensin-converting enzyme genes and coronary artery disease and systemic artery hypertension in African-Brazilians and Caucasian-Brazilians. J Genet. 2016; 95(1):63-9. DOI: 10.1007/s12041-0150599-5

4. Kizilirmak P, Uresin AY. Hypertension and valsartan. Anadolu Kardiyol Derg. 2014; 14 Suppl 2:S20-4. DOI: 10.5152/akd.2014.00004

5. Siddharth KM, Kapur S, Ram CV. Angiotensin converting enzyme gene polymorphism and hypertension: no ace yet in the pack of cards. J Assoc Physicians India.
2012; 60:9-10.

6. Williams RR, Hunt SC, Hasstedt SJ, Hopkins PN, Wu LL, Berry TD, et al. Multigenic human hypertension: evidence for subtypes and hope for haplotypes. J Hypertens Suppl. 1990; 8(7):S39-46.

7. Dudley CR, Giuffra LA, Reeders ST. Identifying genetic determinants in human essential hypertension. J Am Soc Nephrol. 1992; 3(4 Suppl):S2-8.

8. Kunes J, Zicha J. The interaction of genetic and environmental factors in the etiology of hypertension. Physiol Res. 2009; 58 Suppl 2:S33-41.

9. Lind JM, Chiu CL. Genetic discoveries in hypertension: steps on the road to therapeutic translation. Heart. 2013; 99(22):1645-51. DOI: 10.1136/heartjnl-2012-302883

10. Jiang X, Sheng H, Li J, Xun P, Cheng Y, Huang J, et al. Association between renin-angiotensin system gene polymorphism and essential hypertension: a community-based study. J Hum Hypertens. 2009; 23(3):176-81. DOI: $10.1038 /$ jhh.2008.123

11. Zhao J, Qin X, Li S, Zeng Z. Association between the ACE I/D polymorphism and risk of ischemic stroke: an updated meta-analysis of 47,026 subjects from 105 case-control studies. J Neurol Sci. 2014; 345(1-2):3747. DOI: $10.1016 /$ j.jns.2014.07.023

12. Niu W, Qi Y, Hou S, Zhai X, Zhou W, Qiu C. Haplotype-based association of the renin-angiotensin-aldosterone system genes polymorphisms with essential hypertension among Han Chinese: the Fangshan study. J Hypertens. 2009; 27(7):1384-91. DOI: 10.1097/ HJH.0b013e32832b7e0d

13. Niu S, Zhang B, Zhang K, Zhu P, Li J, Sun Y, et al. Synergistic effects of gene polymorphisms of the renin-angiotensin-aldosterone system on essential hypertension in Kazakhs in Xinjiang. Clin Exp Hypertens. 2016; 38(1):63-70. DOI: 10.3109/10641963.2015.1060985

14. He SW, Huang HW, Tan SQ, Fu X, Su LL, Peng DX, et al. Influence of angiotensin-converting enzyme insertion/deletion polymorphism on nitric oxide production in hypertensives and hypercholesterolaemics. J Clin Pharm Ther. 2011; 36(2):187-93. DOI: $10.1111 / \mathrm{j} .1365$ 2710.2010.01176.x

15. Saab YB, Gard PR, Overall AD. The association of hypertension with renin-angiotensin system gene polymorphisms in the Lebanese population. J Renin Angiotensin Aldosterone Syst. 2011; 12(4):588-94. DOI: 10.1177/1470320311408465

16. Rajan S, Ramu P, Umamaheswaran G, Adithan C. Association of aldosterone synthase (CYP11B2 C-344T) gene polymorphism \& susceptibility to essential hypertension in a south Indian Tamil population. Indian J Med Res. 2010; 132:379-85.

17. Chobanian AV, Bakris GL, Black HR, Cushman WC, Green LA, Izzo JL, Jr., et al. Seventh report of the Joint National Committee on Prevention, Detection, Evaluation, and Treatment of High Blood Pressure. 
Hypertension. 2003; 42(6):1206-52. DOI: 10.1161/01. HYP.0000107251.49515.c2

18. Urhan M, Degirmenci I, Harmanci E, Gunes HV, Metintas M, Basaran A. High frequency of DD polymorphism of the angiotensin-converting enzyme gene in Turkish asthmatic patients. Allergy Asthma Proc. 2004; 25(4):243-7.

19. Hulyam K, Aysegul B, Veysi GH, Demet O, Irfan D, Ertugrul C, et al. Frequency of angiotensin II type 1 receptor gene polymorphism in Turkish acute stroke patients. J Cell Mol Med. 2013; 17(4):475-81. DOI: $10.1111 /$ jcmm. 12017

20. Srivastava K, Chandra S, Bhatia J, Narang R, Saluja D. Association of angiotensinogen (M235T) gene polymorphism with blood pressure lowering response to angiotensin converting enzyme inhibitor (Enalapril). J Pharm Pharm Sci. 2012; 15(3):399-406. DOI: 10.18433/J3KW3B

21. Yu H, Zhang Y, Liu G. Relationship between polymorphism of the angiotensin-converting enzyme gene and the response to angiotensin-converting enzyme inhibition in hypertensive patients. Hypertens Res. 2003; 26(11):881-6. DOI: 10.1291/hypres.26.881

22. Voors AA, van Geel PP, Oosterga M, Buikema H, van Veldhuisen DJ, van Gilst WH. Vascular effects of quinapril completely depend on ACE insertion/deletion polymorphism. J Renin Angiotensin Aldosterone Syst. 2004; 5(3):130-4. DOI: 10.3317/jraas.2004.029

23. Ramu P, Umamaheswaran G, Shewade DG, Swaminathan RP, Dutta TK, Balachander J, et al. Candidate Gene Polymorphisms of Renin Angiotensin System and Essential Hypertension in a South Indian Tamilian Population. International Journal of Human Genetics. 2011; 11(1):31-40. DOI: 10.1080/09723757.2011.11886120

24. Rigat B, Hubert C, Alhenc-Gelas F, Cambien F, Corvol $\mathrm{P}$, Soubrier F. An insertion/deletion polymorphism in the angiotensin I-converting enzyme gene accounting for half the variance of serum enzyme levels. J Clin Invest. 1990; 86(4):1343-6. DOI: 10.1172/JCI114844

25. Gunes HV, Ata N, Degirmenci I, Basaran A, Timuralp B, Dikmen M, et al. Frequency of angiotensin-converting enzyme gene polymorphism in Turkish hypertensive patients. Int J Clin Pract. 2004; 58(9):838-43. DOI: 10.1111/j.1742-1241.2004.00206.x

26. Bleumink GS, Schut AF, Sturkenboom MC, van Duijn CM, Deckers JW, Hofman A, et al. Mortality in patients with hypertension on angiotensin-I converting enzyme (ACE)-inhibitor treatment is influenced by the ACE insertion/deletion polymorphism. Pharmacogenet Genomics. 2005; 15(2):75-81. DOI: 10.1097/01213011200502000-00003

27. Degirmenci I, Kebapci N, Basaran A, Efe B, Gunes HV, Akalin A, et al. Frequency of angiotensin-converting enzyme gene polymorphism in Turkish type 2 diabetic patients. Int J Clin Pract. 2005; 59(10):1137-42. DOI: 10.1111/j.1368-5031.2005.00586.x

28. Cosenso-Martin LN, Vaz-de-Melo RO, Pereira LR, Cesarino CB, Yugar-Toledo JC, Cipullo JP, et al. Angiotensin-converting enzyme insertion/deletion polymorphism, 24-h blood pressure profile and left ventricular hypertrophy in hypertensive individuals: a cross-sectional study. European Journal of Medical Research. 2015; 20(1):74. DOI: 10.1186/s40001-015-0166-9

29. Abbas S, Raza ST, Chandra A, Rizvi S, Ahmed F, Eba A, et al. Association of ACE, FABP2 and GST genes polymorphism with essential hypertension risk among a North Indian population. Ann Hum Biol. 2015; 42(5):461-9. DOI: 10.3109/03014460.2014.968206

30. Barley J, Blackwood A, Carter ND, Crews DE, Cruickshank JK, Jeffery S, et al. Angiotensin converting enzyme insertion/deletion polymorphism: association with ethnic origin. J Hypertens. 1994; 12(8):955-7. DOI: $10.1097 / 00004872-199408000-00014$

31. Foy CA, McCormack LJ, Knowler WC, Barrett JH, Catto A, Grant PJ. The angiotensin-I converting enzyme (ACE) gene I/D polymorphism and ACE levels in Pima Indians. J Med Genet. 1996; 33(4):336-7. DOI: 10.1136/jmg.33.4.336

32. Sagnella GA, Rothwell MJ, Onipinla AK, Wicks PD, Cook DG, Cappuccio FP. A population study of ethnic variations in the angiotensin-converting enzyme I/D polymorphism: relationships with gender, hypertension and impaired glucose metabolism. J Hypertens. 1999; 17(5):657-64. DOI: 10.1097/00004872-19991705000009

33. Yi L, Gu YH, Wang XL, An LZ, Xie XD, Shao W, et al. Association of ACE, ACE2 and UTS2 polymorphisms with essential hypertension in Han and Dongxiang populations from north-western China. J Int Med Res. 2006; 34(3):272-83. DOI: 10.1177/147323000603400306

34. Zee RY, Lou YK, Griffiths LR, Morris BJ. Association of a polymorphism of the angiotensin I-converting enzyme gene with essential hypertension. Biochem Biophys Res Commun. 1992; 184(1):9-15. DOI: 10.1016/0006-291X(92)91150-O

35. Zhang J, Zhao B, Gesongluobu, Sun Y, Wu Y, Pei W, et al. Angiotensin-converting enzyme gene insertion/deletion (I/D) polymorphism in hypertensive patients with different degrees of obstructive sleep apnea. Hypertens Res. 2000; 23(5):407-11. DOI: 10.1291/hypres.23.407

36. Yoshida K, Ishigami T, Nakazawa I, Ohno A, Tamura K, Fukuoka M, et al. Association of essential hypertension in elderly Japanese with I/D polymorphism of the angiotensin-converting enzyme (ACE) gene. J Hum Genet. $2000 ; 45(5): 294-8$. DOI: $10.1007 / \mathrm{s} 100380070019$

37. Thomas GN, Tomlinson B, Chan JC, Sanderson JE, Cockram CS, Critchley JA. Renin-angiotensin system gene polymorphisms, blood pressure, dyslipidemia, and diabetes in Hong Kong Chinese: a significant association of the ACE insertion/deletion polymorphism 
with type 2 diabetes. Diabetes Care. 2001; 24(2):35661. DOI: $10.2337 /$ diacare.24.2.356

38. Srivastava K, Sundriyal R, Meena PC, Bhatia J, Narang R, Saluja D. Association of angiotensin converting enzyme (insertion/deletion) gene polymorphism with essential hypertension in northern Indian subjects. Genet Test Mol Biomarkers. 2012; 16(3):174-7. DOI: 10.1089/gtmb.2011.0155

39. Yang YL, Mo YP, He YS, Yang F, Xu Y, Li CC, et al. Correlation between renin-angiotensin system gene polymorphisms and essential hypertension in the Chinese Yi ethnic group. J Renin Angiotensin Aldosterone Syst.
2015; 16(4):975-81. DOI: 10.1177/1470320315598697

40. Togănel R, Muntean I, Duicu C, Făgărăşan A, Gozar L, Bănescu C. The role of eNOS and AGT gene polymorphisms in secondary pulmonary arterial hypertension in Romanian children with congenital heart disease. Rev Romana Med Lab. 2013;21(3):267-74. DOI:10.2478/ rrlm-2013-0031

41. Hu DC, Zhao XL, Shao JC, Wang W, Qian J, Chen AH, et al. Interaction of six candidate genes in essential hypertension. Genet Mol Res. 2014; 13(4):8385-95. DOI: 10.4238/2014.October.20.14 